\title{
Effect of warm-up intensity on horse-rider dyad's performance in jumping
}

\author{
Anna Stachurska ${ }^{1 *}$ Iwona Janczarek $^{1}$ Izabela Wilk $^{1}$ \\ Katarzyna Jaworska ${ }^{1}$ Michal Pluta ${ }^{1}$ Ryszard Kolstrung ${ }^{1}$
}

${ }^{1}$ Department of Horse Breeding and Use, University of Life Sciences in Lublin, Akademicka 13, 20-950, Lublin, Poland. E-mail: anna.stachurska@up.lublin.pl. "Corresponding author.

\begin{abstract}
The aim of this study was to determine whether there is a correlation between the intensity of warm-up and scores of horse-rider dyads in jumping competitions, and which factors affect the warm-up regime. Three international competitions of 120, 130, and $135 \mathrm{~cm}$ obstacle height, completed by 82 competitors, were studied. Warm-up intensity was measured by the time spent in the schooling area, number of practice jumping efforts, and coefficient of practice obstacle height. Out of the official final scores in the competitions, penalty points in the round and converted final placings were used as outcome measures. The data were analyzed with Spearman's correlation, multifactorial analysis of variance, and Tukey's test. The rider's sex, part of the world that the riders came from, horse's sex, age, and competitive level (obstacle height) were considered. Results showed that more jumps and higher obstacles during warm-up decrease the horse-rider dyad's performance in jumping competition, whereas the duration of the total warm-up time does not affect the score. Female riders warm up horses longer but jump lower fences than male riders. Riders do not differentiate the warm-up regime with regard to the horse's sex, whereas they considered the horse's age. The warm-up intensity does not increase proportionally to the competitive level.
\end{abstract}

Key words: equestrian sport, jumping, warm-up, horse, rider.

$O$ efeito da intensidade do aquecimento sobre os resultados de um conjunto cavalo-cavaleiro em competições de saltos

RESUMO: O objetivo do estudo foi determinar se existe uma correlação entre a intensidade do desempenho de aquecimento e os resultados de um conjunto cavalo-cavaleiro em competições de saltos, assim como também determinar os fatores que afetam esta intensidade. Avaliaramse três concursos internacionais com obstáculos de 120, 130 e $135 \mathrm{~cm}$ de altura, que foram completadas por 82 conjuntos. A intensidade do aquecimento foi medida pelo tempo gasto na área de prática, o número de saltos realizados durante o treino e o coeficiente de altura dos obstáculos saltados durante o treino. Dos resultados oficiais finais da competição, utilizaram-se como indicadores os pontos de penalização e o posicionamento obtido. Os dados foram analisados por meio da correlação de Spearman, da análise multivariada de variância e do teste de Tukey. Levaram-se em conta o sexo do cavaleiro, a sua naturalidade; sexo e idade do cavalo e o nível da competição (altura de obstáculos). Os resultados demonstram que quanto mais saltos executados e quanto maiores eram os obstáculos utilizados durante o aquecimento, piores foram os resultados conjunto na competição, contudo, o tempo de aquecimento não afeta os resultados. As amazonas aquecem o cavalo por mais tempo e saltam obstáculos mais baixos do que os homens. Os cavaleiros não diferenciam a intensidade do aquecimento em função do sexo do cavalo, mas, levam em consideração a idade do cavalo. A intensidade do aquecimento não aumenta proporcionalmente com o nível da competição.

Palavras-chave: equitação, saltos, aquecimento, cavalo, cavaleiro.

\section{INTRODUCTION}

Breeding the best athlete horse-jumpers requires an accurate and strong selection that should be performed according to unbiased data on the performance and/or genome. Selection is conducted mainly on the basis of competition or performance test results; however, many factors influence these scores. One such factor may be the intensity of warm-up. During warm-up, subsequent exercises are performed prior to a competition or before a major effort during a workout session. The fact that the warm-up decreases injury risk is of crucial importance and means it cannot be ignored (SAFRAN et al., 1988). According to common equestrian opinions, an appropriate warm-up considerably affects the 
jumping performance in a competition. Thus, a warm-up is commonly recommended in exercise and training programmes of various disciplines. Recent studies have tested the possibility of introducing a whole-body vibration device as a warm-up tool for horses (BUCHNER et al., 2017).

In equestrianism, both horses and riders are warmed up; although, due to the main physical role of the horse, the human's exercise is less accentuated. Through the warm-up, the horse-rider dyad is physically and psychically prepared for the effort. The preliminary effort releases a series of physiological mechanisms in the neuromuscular and cardiorespiratory systems, which are the domain of applied physiology, kinematics, and sports medicine sciences. During highly intensive exercise, the energy supply from aerobic energy sources increases when horses have received a warm-up (TYLER et al., 1996). The prior exercise, in both horses and humans, results in marked increases in $\mathrm{O}_{2}$ supply and utilization, and, as suggested by BURNLEY $\&$ JONES (2005), may improve subsequent severe exercise performance by $2-3 \%$. The warm-up causes an increase in stride length (TRANQUILLE et al., 2014) and range of motion in the horse stifle joint (NORTHROP et al., 2011). The relationship between pre-competitive riders' arousal and perception of their horses' temperament also plays an important role in performance (WOLFRAMM $\&$ MICKLEWRIGHT, 2010). The most important issue is how to optimize the warm-up intensity. Standardbred and Thoroughbred racehorses differ with regard to their reaction to longer or shorter warm-ups (JANSSON, 2005). Too intensive warmup strategies may impair performance and result in the horse's fatigue. Some studies have indicated that even low-intensity warm-up in race horses sufficiently increases the $\mathrm{O}_{2}$ supply (GEOR et al., 2000). However, other findings indicated that higher warm-up intensity still accelerates oxygen consumption-rate kinetics (MUKAI et al., 2010).

Scientific studies mainly investigate the physiology of performance and kinematics in warmed-up horses. We focused on the equestrian aspect of the warm-up — in other words, the performance measured by sports scores obtained after various intensities of the warm-up conducted prior to a jumping competition. The aim of this study was to determine whether there is a correlation between the intensity of the warm-up in the schooling area and the scores of horse-rider dyads in jumping competitions and which factors affect the warm-up regime.

\section{MATERIALS AND METHODS}

The data were collected at the Baltica Equestrian Summer Tour, an international jumping competition held annually in Poland. Warm-ups prior to three competitions were studied. We considered 82 horse-rider dyads in total $(21,42$, and 19) that completed the competitions at the following levels: $120 \mathrm{~cm}, 130 \mathrm{~cm}$, and $135 \mathrm{~cm}$ of obstacle height. The two latter competitions were run over two rounds. Detailed rules of running the competitions are not presented, since they did not interfere with the study. The rider's sex and the part of the world that the athlete came from were considered. Fifty women and 32 men participated in the competitions. The riders came from 17 countries. We split them for the study into two groups: 38 athletes into one group, which included countries in Western, Southern, and Northern Europe as well as other continents, and 44 athletes into another group, which included Central and Eastern Europe. Regarding the horses, 31 mares, 16 stallions, and 35 geldings took part in the competitions. Horses were divided into four age groups: 6 to 7 years, 8 years, 9 to 10 years, and 11 to 15 years. The number of horses in the age groups was $19,22,22$, and 19, respectively.

The warm-up was performed independently by athletes, and we did not interfere with the regime in any way. According to the rules of the FÉDÉRATION EQUESTRE INTERNATIONALE (2016), the schooling area was always supervised by a steward when in use. The area was provided with one vertical and one spread obstacle. A vertical is an obstacle in which all the elements are positioned in the same vertical plane. In the competitions, the spread obstacles were of two vertical planes that built either an oxer or a double bar. The top pole in the further plane of the oxer is situated slightly higher than in the frontal one. The double bar is similar to the oxer, but the top pole in its further plane is situated considerably higher than in the frontal one. Athletes optionally changed the obstacles, providing that the obstacles did not exceed in height and width $10 \mathrm{~cm}$ more than the actual height and width of the obstacles of the competition in progress.

The warm-up of each horse-rider dyad was monitored and filmed beginning with its entering the schooling area until leaving it. The intensity of the warm-up was measured by (1) the time of warm-up (TW), i.e. duration of the time spent in the schooling area in seconds, rounded up to minutes; (2) the number of practice jumping efforts in total (NJ); and (3) the coefficient of practice obstacle height calculated as a 
sum of products of jumping effort number multiplied by the particular height of each obstacle jumped $(\mathrm{OH})$, in centimeters. The width of the spread obstacle was not considered. All jumps were considered regardless of knock-downs, whereas any disobediences were not taken into account.

The outcome measure was the round score. Out of the official final scores in the competitions, penalty points (PPs) and the final placings of competitors (PC) were used as performance indicators. The time of the round was not considered. In the case of two-round competitions, PPs scored only in the first round were taken into account. The first round of two-round competitions is like a oneround competition with regard to the aim of the study. Thus, three competitions could have been considered equally. Moreover, the first round better reflects a possible effect of the intensity of warmup than the final score obtained in the two rounds totally. Conversely, the final placings were also taken into account to determine whether there was an association of the rider-horse dyad's training level with the intensity of warm-up. To make the results more accurate, the final placings were converted into a placing coefficient that amounted the final placing of each competitor divided by the number of competitors in the competition.

Correlations between the traits and competitive scores were calculated using Spearman's correlation coefficient. The hypotheses that assumed a lack of significant differentiation of the intensity of warm-up with regard to the rider's sex (two sexes), part of the world that the riders came from (two parts), horse's sex (three sexes), age (four groups), and competitive level (three competitions) were verified by multivariate analysis of variance using SAS software (SAS, 2003). The results are presented as the means with standard deviations (sd). After the null hypothesis was rejected, a post-hoc comparison of the means was performed using Tukey's HSD test to identify the differences between the groups. Statistical significance was accepted at the level of $\mathrm{P}<0.05$.

\section{RESULTS}

Correlation between PPs and NJ as well as $\mathrm{PC}$ and $\mathrm{OH}$ came out to be positive and significant (Table 1). The correlations between PPs and TW and $\mathrm{OH}$ were low and insignificant. PC was not correlated to TW and NJ either. TW for men $(22.7 \pm 9.8 \mathrm{~min})$ was shorter than for women $(26.7 \pm 8.5 \mathrm{~min})$, NJ was similar in both groups ( $14.2 \pm 4.0$ and $13.3 \pm 3.5$, respectively), and $\mathrm{OH}$ was higher for men $(1551.2 \pm 444 \mathrm{~cm}$ and $1432.8 \pm 366 \mathrm{~cm}$, respectively; Table 2). Riders who came from Central and Eastern Europe had higher NJ and $\mathrm{OH}$ compared to athletes from Western, Southern, and Northern Europe and other continents (Table 3). Horses of different sexes did not differ with regard to TW and NJ (Table 4). Only $\mathrm{OH}$ was higher for geldings. The intensity of warm-up varied across the horses' age (Table 5). TW for 6-7-year-old horses was the longest. $\mathrm{NJ}$ and $\mathrm{OH}$ were the lowest in 9-10-yearolds, higher in 11-15-year-olds, and the highest in 6-7- and 8-year-olds. TW, $\mathrm{NJ}$, and $\mathrm{OH}$ indicated that the intensity of warm-up was significantly highest in the 130-cm obstacle height competition (Table 6). Competitions of 120- and $135-\mathrm{cm}$ obstacle height did not differ with regard to TW and NJ, whereas $\mathrm{OH}$ was higher in the $135-\mathrm{cm}$ competition.

\section{DISCUSSION}

The duration of the total warm-up time in the schooling area that we considered in the study has usually been assumed as a measure of warm-up intensity in most studies in different disciplines. In turn, the duration of the time spent in each pace may be considered as less important in jumping; although, some authors do not ignore it (e.g. WHITAKER et al., 2008). Prior to dressage competitions, different paces and figures during warm-up are of crucial importance (MILLS et al., 2011), and before races when the exercise time and speed in particular paces on the treadmill or with a rider are strictly determined (TYLER et al., 1996; MUKAI et al., 2010). Practice jumps during the warm-up at jumping competitions

Table 1 - Correlations between intensity of warm-up and final results of competitions.

Warm-up intensity - Final results ----Time of warm-up (TW; min)-------Number of jumps (NJ)--- ---Obstacle height coefficient (OH; cm)---

\begin{tabular}{lccc}
\hline Penalty points in round (PPs) & -0.013 & $0.314^{*}$ & 0.161 \\
Placing coefficient (PC) & 0.010 & 0.098 & $0.394^{*}$ \\
\hline
\end{tabular}

${ }^{*}$ Correlations significant at $\mathrm{P}<0.05$. 
Table 2 - Intensity of warm-up with regard to rider's sex.

\begin{tabular}{|c|c|c|c|c|c|c|c|}
\hline \multirow[t]{2}{*}{ Rider's sex } & \multirow[t]{2}{*}{$\mathrm{n}$} & \multicolumn{6}{|c|}{-----Time of warm-up (TW; min)----- --------Number of jumps (NJ)-------- ----Obstacle height coefficient $(\mathrm{OH} ; \mathrm{cm})--}$. \\
\hline & & mean & sd & mean & sd & mean & sd \\
\hline Men & 32 & $22.7 \mathrm{a}$ & 9.8 & $14.2 \mathrm{a}$ & 4.0 & $1551.2 \mathrm{a}$ & 444.5 \\
\hline Women & 50 & $26.7 \mathrm{~b}$ & 8.5 & $13.3 \mathrm{a}$ & 3.5 & $1432.8 \mathrm{~b}$ & 366.0 \\
\hline
\end{tabular}

$\mathrm{n}$ - number of competitors. $\mathrm{a}, \mathrm{b}-$ means in columns marked with different letters differ at $\mathrm{P}<0.05$.

require most effort. It could have been expected that not only the number of jumping efforts but also the practice obstacle size might affect the intensity of the warm-up. A study by FERLAZZO et al. (2012) showed a significant effect of the fence height of competitive exercise in jumping on hypothalamicpituitary-adrenal axis response. Hence, we created the $\mathrm{OH}$, obstacle height coefficient, which regards both the number of jumps and the height of three kinds of obstacles that were jumped: verticals, oxers, and double bars. In spite of the fact that a spread obstacle requires an effort from athletes in both height and spread, fewer faults are committed at double bars (spread obstacle) than at oxers (spread obstacle) and verticals (STACHURSKA et al., 2002). Oxers and verticals do not differ in this respect. Hence, it was not possible to determine a similar coefficient illustrating the difficulty of the spread obstacle, and the width of the spread obstacles was not considered in our study.

Before analyzing factors that influence the warm-up intensity in jumping competitions of the levels studied, we wanted to determine whether a longer warm-up and more practice jumps as well as higher practice obstacles generally improve or impair the horse-rider dyad's performance. The correlations show that the intensity of warm-ups measured with $\mathrm{NJ}$ and $\mathrm{OH}$ is associated with PPs and PC, i.e. the final performance score. However, opposite to athletes' usual expectation, an intensive warm-up decreased the performance. The more frequently a competitor jumped during the warm-up, the more PPs were obtained during the round in a competition, and the higher practice obstacles were jumped, the further the placing. The TW did not affect the final results. Hence, it can be suggested that at this level of competitions, riders and, particularly, horses do not need an intensive warm-up. Exercise prior to a round should be actually warming up and not schooling, which is sometimes performed. It is difficult to state where the threshold is when the warm-up begins to reduce the performance. It was previously documented that, for instance, an excessively high body temperature may contribute to the onset of muscle fatigue (JANSSON, 2005). MURRAY et al. (2006) reported that in dressage competitions, enhanced performance was associated with increased warm-up time and specific warm-up design. However, the authors cautioned that a heavy warm-up might reduce performance. The difference in our results could have been caused by the entirely different character of the disciplines.

The tendency of a negative effect of intensive warm-up found in our study was based on differentiated data and resulted from many factors. Regarding the rider's sex, mean results showed that women warmed up their horses longer than men. However, during that time the women jumped lower obstacles on their horses. This seems to have been due to psychological differences between male and female riders (WOLFRAMM \& MEULENBROEK, 2012; WOLFRAMM et al., 2015). TRANQUILLE et al. (2014) studied the warm-up regime in showjumping and showed inter-rider differences; although, the

Table 3 - Intensity of warm-up with regard to part of the world that riders came from.

\begin{tabular}{|c|c|c|c|c|c|c|c|}
\hline \multirow[t]{2}{*}{ Part of the world } & \multirow[t]{2}{*}{$\mathrm{n}$} & \multicolumn{6}{|c|}{--Time of warm-up (TW; min)-- --Number of jumps (NJ)-- --Obstacle height coefficient $(\mathrm{OH} ; \mathrm{cm})$} \\
\hline & & mean & sd & mean & sd & mean & sd \\
\hline $\begin{array}{l}\text { Western, Southern and Northern } \\
\text { Europe and other continents }\end{array}$ & 38 & $25.0 \mathrm{a}$ & 9.3 & $13.0 \mathrm{a}$ & 3.4 & $1413.9 \mathrm{a}$ & 382.3 \\
\hline Central and Eastern Europe & 44 & $25.2 \mathrm{a}$ & 9.3 & $14.2 \mathrm{~b}$ & 3.9 & $1535.2 \mathrm{~b}$ & 410.8 \\
\hline
\end{tabular}

$\mathrm{n}$ - number of competitors. $\mathrm{a}, \mathrm{b}-$ means in columns marked with different letters differ at $\mathrm{P}<0.05$. 
Table 4 - Intensity of warm-up with regard to horse's sex.

\begin{tabular}{|c|c|c|c|c|c|c|c|}
\hline \multirow[t]{2}{*}{ Horse's sex } & \multirow[t]{2}{*}{$\mathrm{n}$} & \multicolumn{2}{|c|}{-----Time of warm-up (TW; min)----- } & \multicolumn{2}{|c|}{--Number of jumps (NJ)------- } & stacle heig & tt $(\mathrm{OH} ; \mathrm{cm})-$ \\
\hline & & mean & sd & mean & sd & mean & sd \\
\hline Mares & 31 & $25.4 \mathrm{a}$ & 10.1 & $13.3 \mathrm{a}$ & 4.0 & $1440.6 \mathrm{a}$ & 423.1 \\
\hline Stallions & 16 & $24.6 \mathrm{a}$ & 8.8 & $13.5 \mathrm{a}$ & 3.9 & $1465.0 \mathrm{a}$ & 431.4 \\
\hline Geldings & 35 & $25.1 \mathrm{a}$ & 8.9 & $14.1 \mathrm{a}$ & 3.4 & $1519.4 b$ & 371.7 \\
\hline
\end{tabular}

$\mathrm{n}$ - number of competitors. $\mathrm{a}, \mathrm{b}-$ means in columns marked with different letters differ at $\mathrm{P}<0.05$.

sex was not taken into account. The mean warm-up duration equalled $18 \mathrm{~min}$ in a range of $12-27 \mathrm{~min}$ in that study. Although, equestrianism enables to compare male and female sporting performance within the same competition, there are few studies on that subject. According to WHITAKER \& WOLFRAMM (2012), more men than women compete at the international elite level in jumping, whereas their final rankings are similar. The latter may result from a lower rider effect compared to the horse's impact.

Inter-country differences in warm-up practices in dressage were reported by MURRAY et al. (2006). Classification of athletes in our study was based on the general level of equestrianism in the world. As world rankings show, equestrian sports, particularly jumping, are more developed in socalled Western European countries because, among others, they require considerable funds. The fact that competitors coming from Central and Eastern Europe jumped practice obstacles more frequently and the obstacles were higher compared to athletes from Western, Southern, and Northern Europe and other continents may indicate that the former could have been less experienced. In light of the correlation with the final score, those athletes could have also been of minor performance.

Horses of different sexes had similar coaching in the schooling area. These results showed that riders do not differentiate the warm-up with regard to the horse's sex. Instead, the horse's age is of more importance for the riders. Athletes exercise the youngest horses more intensively, perhaps because of the belief that young horses are strong enough and that during the warm-up they can still learn. The 9-10-year-olds are treated as being at the top of their career, strong, and well-schooled; hence, they are warmed up less intensively. In turn, the warmup of the older horses was heavier again, and this is difficult to interpret. It seems that those horses are already well experienced and usually begin to age, and thus their energy should be saved.

Considering our three measures of the warm-up intensity (TW, $\mathrm{NJ}$, and $\mathrm{OH}$ ), it may be inferred that the warm-ups do not increase proportionally to the competitive level in jumping. The warm-up at the lower level was less intensive than at the intermediate level; however, it decreased again at the highest level. With regard to the two lower competitive levels, these results agree with WHITAKER et al. (2008); although, the mean total warm-up time was shorter in that study $(15.0-17.7 \mathrm{~min})$. Competitors at the intermediate competitive level warmed up more heavily. The decrease of the warm-up intensity at the next level in our study (135-cm obstacle) may be connected with the increasing experience and enhanced performance of the horse-rider dyads. It is likely that the riders at this competitive level believe their horses do not need a heavy warm-up. However,

Table 5 - Intensity of warm-up with regard to horse's age.

\begin{tabular}{|c|c|c|c|c|c|c|c|}
\hline \multirow[t]{2}{*}{ Horse's age group (years) } & \multirow[t]{2}{*}{$\mathrm{n}$} & \multicolumn{6}{|c|}{---Time of warm-up (TW; min)--- ----Number of jumps (NJ)---- --Obstacle height coefficient $(\mathrm{OH}$; $\mathrm{cm})$-- } \\
\hline & & mean & sd & mean & sd & mean & sd \\
\hline $6-7$ & 19 & $27.4 \mathrm{a}$ & 8.6 & $14.5 \mathrm{a}$ & 4.1 & $1585.8 \mathrm{a}$ & 446.1 \\
\hline 8 & 22 & $23.4 \mathrm{~b}$ & 7.8 & $14.4 \mathrm{a}$ & 3.7 & $1547.3 \mathrm{a}$ & 390.7 \\
\hline $9-10$ & 22 & $24.5 \mathrm{~b}$ & 10.6 & $12.4 \mathrm{~b}$ & 3.1 & $1342.7 \mathrm{~b}$ & 339.3 \\
\hline $11-15$ & 19 & $25.2 \mathrm{~b}$ & 10.0 & $13.7 \mathrm{c}$ & 3.8 & $1476.7 \mathrm{c}$ & 405.2 \\
\hline
\end{tabular}

$\mathrm{n}$ - number of competitors. $\mathrm{a}, \mathrm{b}, \mathrm{c}-$ means in columns marked with different letters differ at $\mathrm{P}<0.05$.

Ciência Rural, v.48, n.2, 2018. 
Table 6 - Intensity of warm-up with regard to competitive level.

\begin{tabular}{|c|c|c|c|c|c|c|c|}
\hline \multirow[t]{2}{*}{ Competitive level (obstacle height in $\mathrm{cm}$ ) } & \multirow[t]{2}{*}{$\mathrm{N}$} & \multicolumn{2}{|c|}{ Time of warm-up (TW; min) } & \multicolumn{2}{|c|}{ Number of jumps (NJ) } & \multicolumn{2}{|c|}{ Obstacle height coefficient $(\mathrm{OH} ; \mathrm{cm})$} \\
\hline & & mean & sd & mean & sd & mean & sd \\
\hline 120 & 21 & $24.0 \mathrm{a}$ & 10.0 & $11.2 \mathrm{a}$ & 2.6 & $1210.9 \mathrm{a}$ & 285.5 \\
\hline 130 & 42 & $26.1 \mathrm{~b}$ & 8.0 & $15.5 \mathrm{~b}$ & 3.8 & $1680.9 \mathrm{~b}$ & 410.3 \\
\hline 135 & 19 & $24.0 \mathrm{a}$ & 10.9 & $12.3 \mathrm{a}$ & 1.9 & $1328.9 \mathrm{c}$ & 208.6 \\
\hline
\end{tabular}

$\mathrm{n}$ - number of competitors. a, b, c - means in columns marked with different letters differ at $\mathrm{P}<0.05$.

this decrease does not agree with the above-discussed tendency of an increased warm-up of older horses. $\mathrm{OH}$ rising with competitive levels was expected according to the jumping rules. However, $\mathrm{OH}$ at the highest competitive level was not high. This showed that the riders did not use their right to jump higher obstacles prior to this competition but rather credited the horses with their abilities at this competitive level.

To conclude, the intensity of a warm-up is associated with the final competition score and differentiated according to various factors. More jumps and higher obstacles during warm-up decrease the horse-rider dyad's performance in jumping measured by the final score, whereas the duration of the total warm-up time does not affect the score. Female riders warm up their horses for longer but jump lower fences than male riders. The riders do not differentiate the warm-up regime with regard to the horse's sex, whereas they consider the horse's age. Nine-10-year-old horses are warmed up less intensively. The warm-up intensity does not increase proportionally to the competitive level in jumping. Both breeders and riders should realize which factors connected with the intensity of the warm-up influence the final competition score.

\section{ACKNOWLEDGEMENTS}

The study was founded by the University of Life Sciences in Lublin (ZKK-DS/3 project). The authors are thankful to riders who agreed that the warm-up of horse-rider dyads was analysed.

\section{BIOETHICS AND BIOSSECURITY COMMITTEE APPROVAL}

The study did not need the Bioethics and Biossecurity Committee approval since it did not interfere in the warm-up of horses and competition procedure.

\section{REFERENCES}

BUCHNER, H.H.F. et al. Effects of whole body vibration on the horse: actual vibration, muscle activity, and warm-up effect. Journal of Equine Veterinary Science, v.51, p.54-60, 2017. Available from:
<http://www.j-evs.com/article/S0737-0806(16)30112-5>. Accessed: Apr. 11, 2017. doi: 10.1016/j.jevs.2016.12.005.

BURNLEY, M.; JONES, A.M. Effects of 'warm-up' exercise on energy provision and exercise performance in horses and humans: a comparative review. Equine and Comparative Exercise Physiology, v.2, p.135-147, 2005. Available from: $<$ https://www.researchgate.net/journal/1479-070X_Equine_ and_Comparative_Exercise_Physiology>. Accessed: Mar. 25, 2017. doi: $10.107 \overline{9} / \mathrm{ECP} 200561$.

GEOR, R.J. et al. Effects of warm-up intensity on kinetics of oxygen consumption and carbon dioxide production during highintensity exercise in horses. American Journal of Veterinary Research, v.61, p.638-645, 2000. Available from: <https://www. ncbi.nlm.nih.gov/pubmed/10850838>. Accessed Mar. 24, 2017.

FERLAZZO, A. et al. Circulating ß-endorphin, adrenocorticotropin, and cortisol concentrations of horses before and after competitive show jumping with different fence heights. Journal of Equine Veterinary Science, v.32, p.740-746, 2012. Available from: $<$ http:// www.sciencedirect.com/science/article/pii/S0737080612000974>. Accessed: Mar. 23, 2017. doi: 10.1016/j.jevs.2012.02.021.

JANSSON, A. A field study on warm-up regimes for Thoroughbred and Standardbred racehorses. Equine and Comparative Exercise Physiology, v.2, p.219-224, 2005. Available from: $<$ http://www.wageningenacademic.com/pb-assets/wagen/files/ cep/cep_back_issues/ECP200572.pdf>. Accessed: Mar. 24, 2017. doi: $10 . \overline{1}$ 1079/ECP200572.

FÉDÉRATION EQUESTRE INTERNATIONALE. Jumping Rules. Retrieved from: <http://www.fei.org>, 2016.

MILLS, A.A. et al. A comparative study of pirouettes practiced in the warm-up and subsequent performance in elite (Grand Prix) level dressage competition. $7^{\text {th }}$ International Equitation Science Conference, Hooge Mierde, The Netherlands, $27^{\text {th }}-29^{\text {th }}$ October 2011. Proceedings. International Society of Equitation Science, p.35, 2011.

MUKAI, K. et al. Effects of three warm-up regimens of equal distance on $\mathrm{VO}_{2}$ kinetics during supramaximal exercise in Thoroughbred horses. Equine Veterinary Journal, v.42 (supl.38), p.33-39, 2010. Accessed: Mar. 22, 2017. Available from: <http:// onlinelibrary.wiley.com/doi/10.1111/j.2042-3306.2010.00227.x/ epdf> doi: 10.1111/j.2042-3306.2010.00227.x.

MURRAY, R.C. et al. Warm-up in dressage competitions: association with level, competition type and final score. Equine and Comparative Exercise Physiology, v.3, p.185189, 2006. Available from: <http://onlinelibrary.wiley.com/ 
doi/10.1111/j.2042-3306.2006.tb05578.x>. Accessed: Apr. 22, 2017. doi: 10.1111/j.2042-3306.2006.tb05578.x.

NORTHROP, A.J. et al. Effects of warm up on stride characteristics in the horse: a preliminary study. $7^{\text {th }}$ International Equitation Science Conference, Hooge Mierde, The Netherlands, 27 $7^{\text {th }}-29^{\text {th }}$ October 2011. Proceedings. International Society of Equitation Science, p.92, 2011.

SAFRAN, M. et al. The role of warm-up in muscular injury prevention. The American Journal of Sports Medicine, v.16, p.123-129, 1988. Available from: <https://www.ncbi.nlm.nih.gov/ pubmed/3377095>. Accessed Mar. 20, 2017.

SAS Institute Incorporated. C. N. U. SAS user's guide statistics: Version 9.1.3. Cary NC, 2003.

STACHURSKA, A. et al. Which obstacles are most problematic for jumping horses? Applied Animal Behaviour Science, v.77, p.197207, 2002. Available from: <http://www.appliedanimalbehaviour. com/article/S0168-1591(02)00042-4>. Accessed: April 20, 2017. doi: 10.1016/S0168-1591(02)00042-4.

TRANQUILLE, C. et al. Quantifying warm-up in showjumping horses over 3 consecutive days. Equine Veterinary Journal, v.46 (supl.46), p.10-11. Abstracts from the $9^{\text {th }}$ International Conference on Equine Exercise Physiology, 15-20 June, 2014, Chester, UK, 2014.

TYLER, C.M. et al. Effect of warm-up on energy supply during high intensity exercise in horses. Equine Veterinary Journal, v.28, p.117-120, 1996. Available from: <http://onlinelibrary.wiley. com/doi/10.1111/j.2042-3306.1996.tb01602.x/full>. Accessed: Jan. 20, 2017. doi: 10.1111/j.2042-3306.1996.tb01602.x.

WHITAKER, T.C. et al. Horse warm-up regimes at two different competitive levels of show jumping: a pilot study. Comparative
Exercise Physiology, v.5, p.105-106, 2008. Available from: $<$ http://www.wageningenacademic.com/pb-assets/wagen/files/ cep/cep_back_issues/S1478061508120254a.pdf $>$. Accessed: Feb. 25, 2017. doi: $10.1017 / \mathrm{S} 1478061508120254$.

WHITAKER T.et al. Differences in elite showjumping performance between male and female riders. International Journal of Performance Analysis in Sport, v.12, issue 2, 2012. Available from: <http://www.tandfonline.com/doi/abs/10.108 0/24748668.2012.11868608>. Accessed: Mar. 22, 2017. doi: $10.1080 / 24748668.2012 .11868608$.

WOLFRAMM, I.A.; MICKLEWRIGHT, D. Pre-competitive arousal, perception of equine temperament and riding performance: do they interact? Comparative Exercise Physiology, v.7, p.27-36, 2010. Available from: <https:// www.cambridge.org/core/journals/comparative-exercisephysiology/article/precompetitive-arousal-perception-ofequine-temperament-and-riding-performance-do-they-interact/ AADBDF69F28EF9F8B284E761A182AFA6>. Accessed Mar. 22, 2017. doi: 10.1017/S1755254010000152.

WOLFRAMM, I.A.; MEULENBROEK, R.G.J. Co-variations between perceived personality traits and quality of the interaction between female riders and horses. Applied Animal Behaviour Science, v.139, p.96-104, 2012. Available from: <https:// pdfs.semanticscholar.org/5ed7/25ad5e 7223692b0125762a93 525e479b219a.pdf>. Accessed: Apr. 22, 2017. doi: 10.1016/j. applanim.2012.03.006.

WOLFRAMM, I.A. et al. The role of personality in equestrain sports: an investigation. Comparative Exercise Physiology, v.11, p.133144, 2015. Available from: <http:/www.wageningenacademic. com/doi/abs/10.3920/CEP150002>. Accessed: March 20, 2017. doi: 10.3920/CEP150002. 